\title{
Lethal endotoxic shock using $\alpha$-galactosylceramide sensitization as a new experimental model of septic shock
}

\author{
Hiroyasu Ito ${ }^{1}$, Naoki Koide ${ }^{1}$, Ferdaus Hassan $^{1}$, Shamima Islam ${ }^{1}$, Gantsetseg Tumurkhuu ${ }^{1}$, \\ Isamu Mori ${ }^{1}$, Tomoaki Yoshida ${ }^{1}$, Shinichi Kakumu ${ }^{2}$, Hisataka Moriwaki ${ }^{3}$ and \\ Takashi Yokochi ${ }^{1}$ \\ ${ }^{1}$ Department of Microbiology and Immunology, Aichi Medical University School of Medicine, Nagakute, \\ Aichi, Japan; ${ }^{2}$ Department of Internal Medicine, Aichi Medical University School of Medicine, Nagakute, \\ Aichi, Japan and ${ }^{3}$ First Department of Internal Medicine, Gifu University School of Medicine, Gifu, Japan
}

\begin{abstract}
The effect of $\alpha$-galactosylceramide ( $\alpha$-GalCer) on lipopolysaccharide (LPS)-mediated lethality was examined. Administration of LPS killed all mice pretreated with $\alpha$-GalCer, but not untreated control mice. The lethal shock in $\alpha$-GalCer-sensitized mice was accompanied by severe pulmonary lesions with marked infiltration of inflammatory cells and massive cell death. On the other hand, hepatic lesions were focal and mild. A number of cells in pulmonary and hepatic lesions underwent apoptotic cell death. $\alpha$-GalCer sensitization was ineffective for the development of the systemic lethal shock in $V \alpha 14$-positive natural killer $T$ cell-deficient mice. Sensitization with $\alpha$-GalCer led to the circulation of a high level of interferon (IFN)- $\gamma$ and further augmented the production of tumor necrosis factor (TNF)- $\alpha$ in response to LPS. The lethal shock was abolished by the administration of anti-IFN- $\gamma$ or TNF- $\alpha$ antibody. Further, the lethal shock did not occur in TNF- $\alpha$-deficient mice. Taken together, $\alpha$-GalCer sensitization rendered mice very susceptible to LPS-mediated lethal shock, and IFN- $\gamma$ and TNF- $\alpha$ were found to play a critical role in the preparation and execution of the systemic lethal shock, respectively. The LPS-mediated lethal shock using $\alpha$-GalCer sensitization might be useful for researchers employing experimental models of sepsis and septic shock.
\end{abstract}

Laboratory Investigation (2006) 86, 254-261. doi:10.1038/labinvest.3700388; published online 30 January 2006

Keywords: lipopolysaccharide; NKT cell; $\alpha$-galactosylceramide; septic shock; cytokine

A number of useful animal models for sepsis and septic shock have been described, which substantially facilitate sepsis-related research and provide the powerful tools to resolve problems related to the sepsis syndrome. ${ }^{1}$ Further, these models will be invaluable in improving our understanding of pathophysiology and in developing new and more effective approaches toward therapy. ${ }^{1}$ Lipopolysaccharide (LPS) is known to cause the systemic inflammatory response syndrome, endotoxic shock, disseminated intravascular coagulation and multiorgan failure. LPS-mediated lethality has been characterized by a number of laboratory models

Correspondence: Dr H Ito, MD, PhD, Department of Microbiology and Immunology, Aichi Medical University School of Medicine, Nagakute, Aichi 480-1195, Japan.

E-mail: hito@aichi-med-u.ac.jp

Received 27 September 2005; revised and accepted 9 December 2005; published online 30 January 2006 using sensitization with D-galactosamine, ${ }^{2}$ Propionibacterium parvum, ${ }^{3} \mathrm{BCG}^{4}$ and CpG DNA. ${ }^{5}$ Generalized Shwartzman reaction is a potentially lethal shock reaction, which can be induced by the administration of LPS into LPS-primed animals at an interval of $24 \mathrm{~h}^{6}{ }^{6}$ None of them presents respiratory failure, a typical manifestation in severe septic patients. Therefore, there is a need for an animal model of severe sepsis characterized by respiratory failure severe enough to require mechanical ventilation. ${ }^{1}$

Recently, we have found that $\alpha$-galactosylceramide ( $\alpha$-GalCer) augments LPS-induced nitric oxide (NO) production in mouse peritoneal cells through the release of interferon (IFN)- $\gamma$ from V $\alpha 14$-positive natural killer T (NKT) cells. ${ }^{7}$ Therefore, we studied the in vivo action of $\alpha$-GalCer on LPS-induced NO production in mice. Surprisingly, pretreatment of mice with $\alpha$-GalCer caused systemic lethal shock with severe lung injury after LPS challenge. In the 
present study, we examined the mechanism of how $\alpha$-GalCer sensitization rendered mice susceptible to LPS-mediated lethal shock. Here, we discuss clinical usefulness of the model using $\alpha$-GalCer sensitization in sepsis and septic shock-related research.

\section{Materials and methods}

\section{Mice}

BALB/c and C57BL/6 mice of approximately 7 weeks of age were supplied by Japan SLC (Hamamatsu, Japan). J $\alpha 281$ T-cell receptor-deficient mice ${ }^{8}$ as NKT cell-deficient mice were kindly provided by $\mathrm{T}$ Nakayama (Chiba University) and M Taniguchi (RIKEN Research Center). Tumor necrosis factor (TNF)- $\alpha$-deficient mice were from K Sekikawa (National Institute of Animal Health) and K Saito (Gifu University). All animal experiments were approved by the Animal Care Committee and carried out under the guide for care and use of laboratory animals (Aichi Medical University).

\section{Reagents}

$\alpha$-GalCer (KRN7000) was synthesized and provided by Kirin Brewery Company (Gunma, Japan). LPS from Escherichia coli O55:B5 was obtained from Sigma Chemicals (St Louis, MO, USA). A monoclonal antibody to murine IFN- $\gamma$ or TNF- $\alpha$ was obtained from R\&D Systems (Minneapolis, MN, USA).

\section{Induction of LPS-Mediated Lethal Shock}

Mice were injected intravenously (i.v.) with $\alpha$ GalCer $(1 \mu \mathrm{g})$ for sensitization and then challenged i.v. with LPS $(5 \mu \mathrm{g}) 12 \mathrm{~h}$ later, unless otherwise stated. Approximately six mice were used in each experimental group. The lethality was determined at $24 \mathrm{~h}$ after LPS administration.

\section{Histology}

Various organs were removed from exanguinated mice $8 \mathrm{~h}$ after LPS administration, fixed with $10 \%$ formalin or Carnoy's fixative, and stained with hematoxylin and eosin. Histological changes were observed and photographs were taken by the Fujix digital camera HC-2500 under an Olympus BX50 microscope. The digital images were processed by the computer software.

\section{Terminal Deoxynucleotidyl Transferase-Mediated Nick-End Labeling (TUNEL) Specific for Fragmented DNA}

Mice were killed $8 \mathrm{~h}$ after LPS treatment. Lungs and livers were removed, fixed with formalin and cut serially into $4-6 \mu \mathrm{m}$ sections. The sections were deparaffinized and was stained for the detection of fragmented DNA by the TUNEL method as described previously. ${ }^{9,10}$

\section{Determination of IFN- $\gamma$ and TNF- $\alpha$}

The concentrations of circulating TNF- $\alpha$ and IFN- $\gamma$ in the sera were determined by an enzyme-linked absorbent assay kit for TNF- $\alpha$ or IFN- $\gamma$ (Biosource International, Camarillo, CA, USA), respectively, according to the manufacturer's instruction. Experimental results are expressed as the mean of triplicates \pm s.d. in three independent experiments.

\section{Determination of Alanine Aminotransferase (ALT)}

Serum samples from individual mice were obtained from the retro-orbital venous plexus, and the serum ALT levels were determined using a Hitachi 7700 autoanalyzer.

\section{Results}

\section{Induction of Lethal Shock by the Administration of LPS into $\alpha$-GalCer-Sensitized Mice}

Development of lethal shock was examined by the injection of various doses of LPS into $\alpha$-GalCersensitized mice. Mice were sensitized by an i.v. injection of $\alpha$-GalCer $(1 \mu \mathrm{g}) 12 \mathrm{~h}$ before LPS injection and the dose-dependent effect of LPS on the lethality of $\alpha$-GalCer-sensitized mice was examined (Table 1). All $\alpha$-GalCer-sensitized C57BL/6 mice died within $24 \mathrm{~h}$ after an i.v. injection of $1 \mu \mathrm{g}$ of LPS, whereas $\alpha$-GalCer-sensitized BALB/c mice required $5 \mu \mathrm{g}$ of LPS as the lethal dose. C57BL/6 mice seemed more susceptible for LPS-mediated lethal shock than BALB/C mice.

In order to determine the priming dose of $\alpha$-GalCer for sensitization, C57BL/6 mice were sensitized by i.v. injections with various doses of $\alpha$-GalCer and challenged by LPS ( 1 and $5 \mu \mathrm{g}$ ). The lethality was

Table 1 Effect of various concentrations of LPS on lethality

\begin{tabular}{lcccc}
\hline Mouse & $\alpha$-GalCer $(\mu g)$ & Time $(h)^{\mathrm{a}}$ & LPS $(\mu g)$ & $\begin{array}{c}\text { Lethality } \\
\text { (dead/total) }\end{array}$ \\
\hline C57B6 & 1 & 12 & 0.1 & $0 / 6$ \\
C57B6 & 1 & 12 & 0.5 & $4 / 6$ \\
C57B6 & 1 & 12 & 1 & $6 / 6$ \\
C57B6 & 1 & 12 & 5 & $6 / 6$ \\
C57B6 & 1 & 12 & 10 & $6 / 6$ \\
BALB/c & 1 & 12 & 0.5 & $0 / 6$ \\
BALB/c & 1 & 12 & 1 & $0 / 6$ \\
BALB/c & 1 & 12 & 5 & $6 / 6$ \\
BALB/c & 1 & 12 & 10 & $6 / 6$ \\
BALB/c & 1 & 12 & 100 & $6 / 6$ \\
\hline
\end{tabular}

\footnotetext{
${ }^{\mathrm{a}}$ Hours before LPS administration.
} 
determined $24 \mathrm{~h}$ after LPS injection (Table 2). Sensitization with $1 \mu \mathrm{g}$ of $\alpha$-GalCer killed all the mice. However, priming with $0.1 \mu \mathrm{g}$ of $\alpha$-GalCer was not effective for the development of LPS-mediated lethal shock.

Effect of various time intervals between injections of $\alpha$-GalCer and LPS on the lethality was examined (Table 3). Simultaneous administration of $\alpha$-GalCer and LPS was ineffective for the development of the lethal shock. The minimal interval time between injections of $\alpha$-GalCer and LPS needed $3 \mathrm{~h}$ for the development. The administration of LPS $48 \mathrm{~h}$ after $\alpha$ GalCer priming did not cause the lethal shock. Successful sensitization with $\alpha$-GalCer for the development of the lethal shock required the

Table 2 Effect of various concentrations of $\alpha$-GalCer on lethality

\begin{tabular}{lcccc}
\hline Mouse & $\alpha$-GalCer $(\mu g)$ & Time $(h)^{\mathrm{a}}$ & LPS $(\mu g)$ & $\begin{array}{c}\text { Lethality } \\
\text { (dead/total) }\end{array}$ \\
\hline C57B6 & 0.01 & 12 & 5 & $0 / 6$ \\
C57B6 & 0.1 & 12 & 5 & $0 / 6$ \\
C57B6 & 1 & 12 & 5 & $6 / 6$ \\
C57B6 & 1 & 12 & 1 & $6 / 6$ \\
\hline
\end{tabular}

${ }^{\mathrm{a}}$ Hours before LPS administration. interval period from 3 to $24 \mathrm{~h}$ between injections of $\alpha$-GalCer and LPS. In following experiments, the priming with $\alpha$-GalCer was carried out $12 \mathrm{~h}$ before LPS treatment.

\section{Histological Changes in Various Organs of Mice with Lethal Shock}

Histological change in various organs of BALB/C mice with the lethal shock (Figure 1) was examined $8 \mathrm{~h}$ after LPS injection. In the lungs, there was marked accumulation of a large number of infiltrates consisting of polymorphonuclear leukocytes and

Table 3 Time course of $\alpha$-GalCer pretreatment on LPS-induced lethality

\begin{tabular}{lcccc}
\hline Mouse & $\alpha$-GalCer $(\mu g)$ & Time $(h)^{\mathrm{a}}$ & LPS $(\mu g)$ & $\begin{array}{c}\text { Lethality } \\
\text { (dead/total) }\end{array}$ \\
\hline C57B6 & 1 & 0 & 5 & $0 / 6$ \\
C57B6 & 1 & 3 & 5 & $6 / 6$ \\
C57B6 & 1 & 6 & 5 & $6 / 6$ \\
C57B6 & 1 & 24 & 5 & $6 / 6$ \\
C57B6 & 1 & 48 & 5 & $0 / 6$ \\
\hline
\end{tabular}

${ }^{\mathrm{a}}$ Hours before LPS administration.

\section{$\alpha-$ GalCer + LPS}
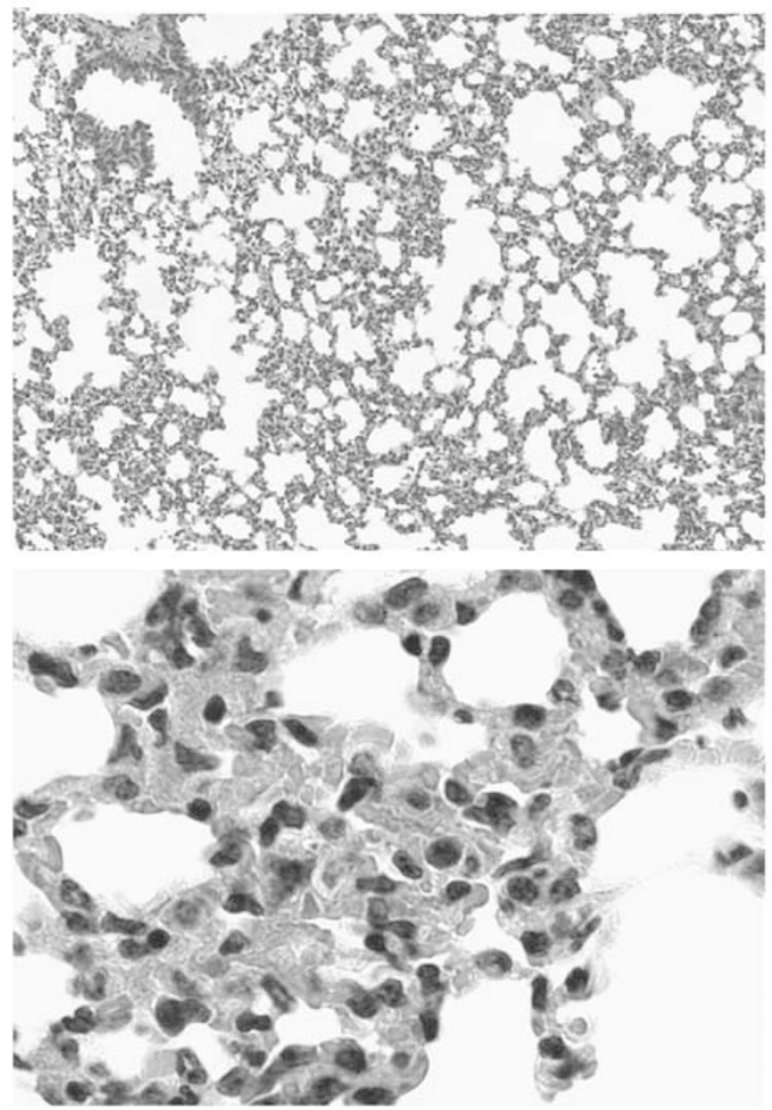

LPS

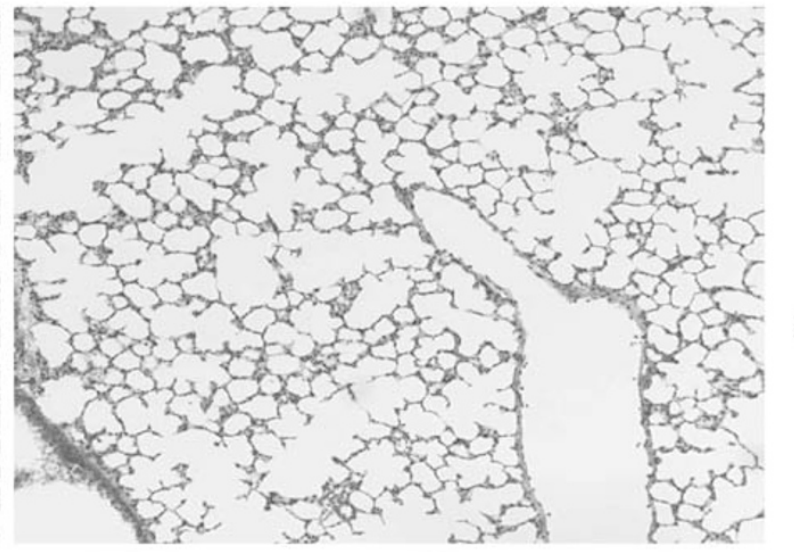

x 200

$x 1000$

Figure 1 Histological changes in the lungs of mice with lethal shock. BALB/c mice were primed i.v. with $\alpha$-GalCer ( $1 \mu \mathrm{g})$, and $12 \mathrm{~h}$ later, injected i.v. with LPS ( $5 \mu \mathrm{g})$. The lungs were removed $8 \mathrm{~h}$ after LPS injection. The sections were stained with hematoxylin-eosin. Low magnification, $\times 200$; high magnification, $\times 1000$. 
mononuclear cells (Figure 1). Hemorrhage and cell destruction were also seen. On the other hand, there were no significant changes in the lungs of mice receiving an injection of LPS alone. Hepatic lesions in those mice were characterized by focal infiltration of inflammatory cells, such as polymorphonuclear leukocytes and mononuclear cells and slight hemorrhages (Figure 2a). Hepatic lesions were less severe compared with pulmonary lesions. The serum ALT was also elevated in the mice with lethal shock, suggesting hepatic injuries (Figure 2b). In other organs, there was no significant histological change, except congestion.

\section{Detection of Apoptotic Cells in the Lungs and Livers from Mice with Lethal Shock}

In order to clarify the mechanism of cell death in the lethal shock, apoptotic cells in the lungs and livers were stained by TUNEL specific for fragmented DNA (Figure 3). A number of positively stained cells were seen in the lungs of BALB/c mice treated with $\alpha$ GalCer and LPS, whereas few positive cells were seen in the case of mice treated with $\alpha$-GalCer or LPS alone.
Positive cells were also seen in the livers from the mice and positively stained cells were hepatocytes.

\section{No Induction of Lethal Shock in V $\alpha 14-P o s i t i v e$ NKT-Deficient Mice}

The LPS-mediated lethality with $\alpha$-GalCer sensitization was examined by using NKT-deficient BALB/c or wild-type BALB/c mice (Table 4). Wild-type and NKT-deficient BALB/c mice were sensitized with $\alpha$ GalCer $(1 \mu \mathrm{g})$, and $12 \mathrm{~h}$ later, LPS ( $5 \mu \mathrm{g})$ was injected into the mice. The injection of LPS killed none of NKT-deficient mice, although it killed all wild-type BALB/c mice. Further, there was no significant histological change in the lungs of NKT-deficient mice receiving an injection of $\alpha$-GalCer and LPS (Figure 4). On the other hand, the lungs of wild-type BALB/c mice were characterized by the accumulation of a large number of infiltrates consisting of polymorphonuclear leukocytes and mononuclear cells.

The administration of a high dose (1 $\mathrm{mg}$ ) of LPS killed both NKT-deficient and wild-type mice in the case of no $\alpha$-GalCer sensitization. a

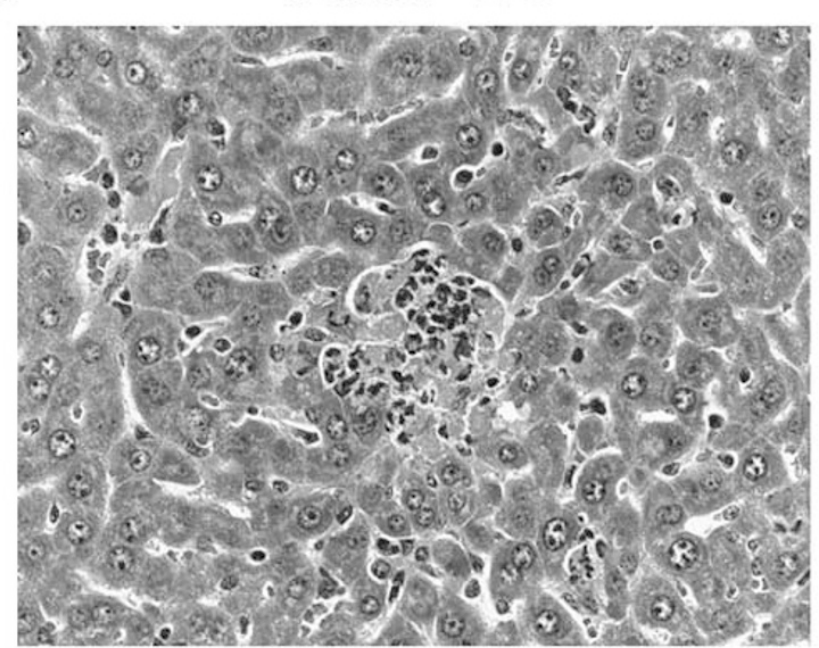

LPS

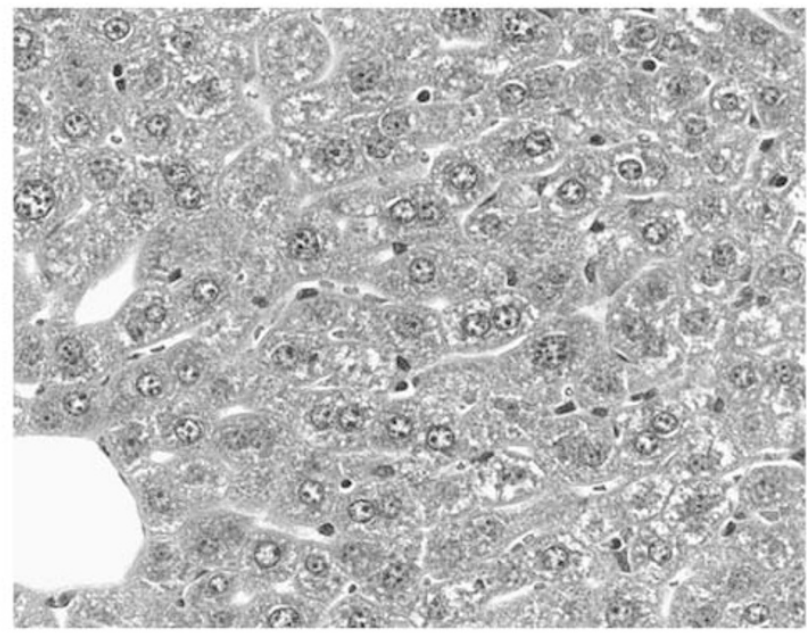

b

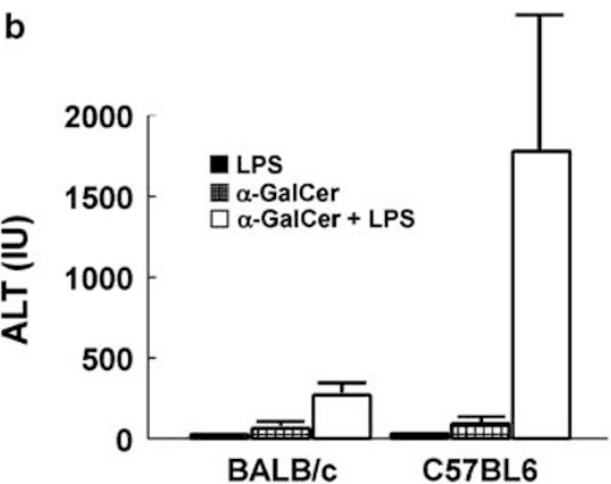

Figure 2 Hepatic injuries in the livers of mice with lethal shock. BALB/c mice were primed i.v. with $\alpha$-GalCer ( $1 \mu \mathrm{g}$ ), and $12 \mathrm{~h}$ later, injected i.v. with LPS $(5 \mu \mathrm{g})$. (a) Histology of the livers. The livers were removed $8 \mathrm{~h}$ after LPS injection, The sections were stained with hematoxylin-eosin. High magnification, $\times 400$. (b) Serum ALT activity. Blood was taken from the mice $8 \mathrm{~h}$ after LPS treatment and the serum ALT activities were determined. Each value represents the mean \pm s.d. of triplicate samples. 


\section{$\alpha-$ GalCer + LPS}
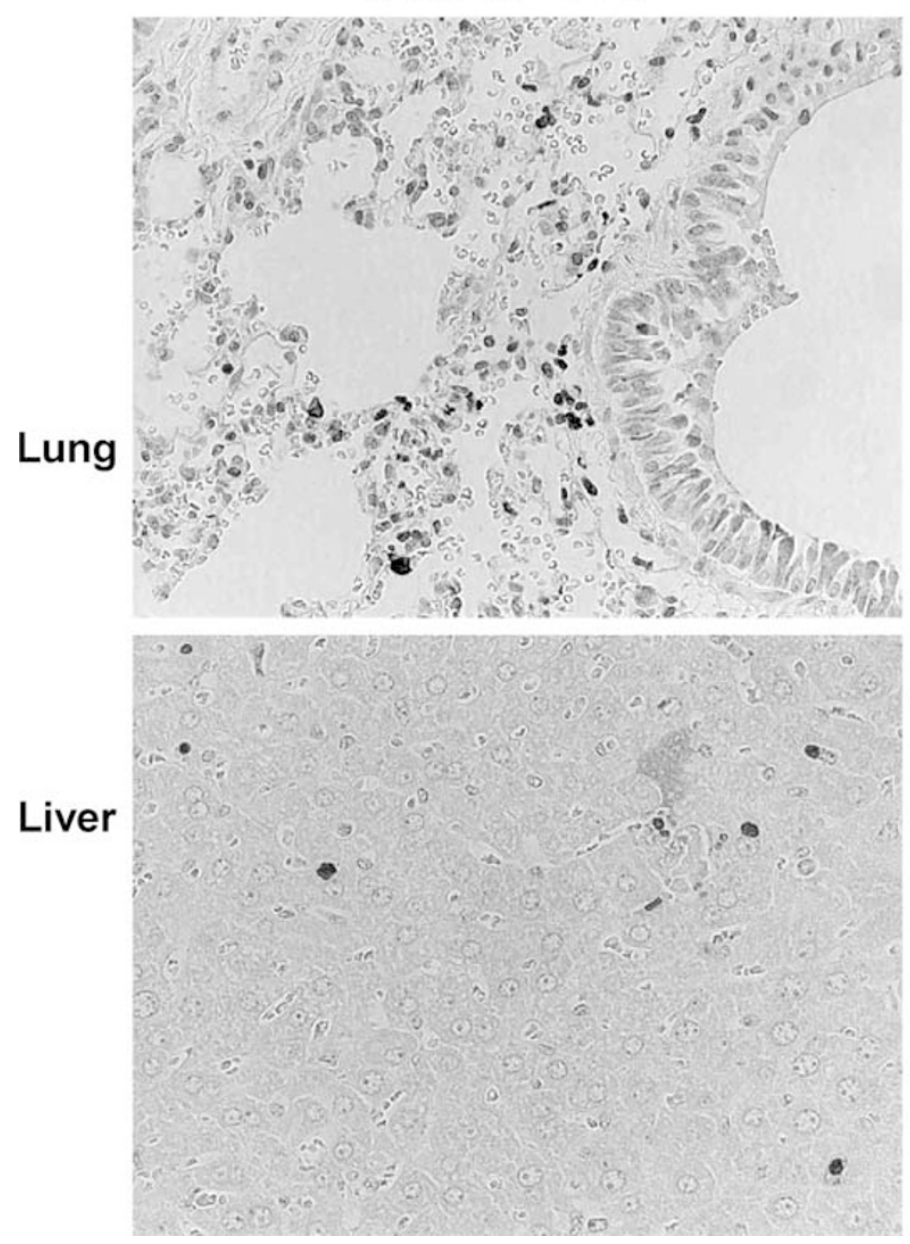
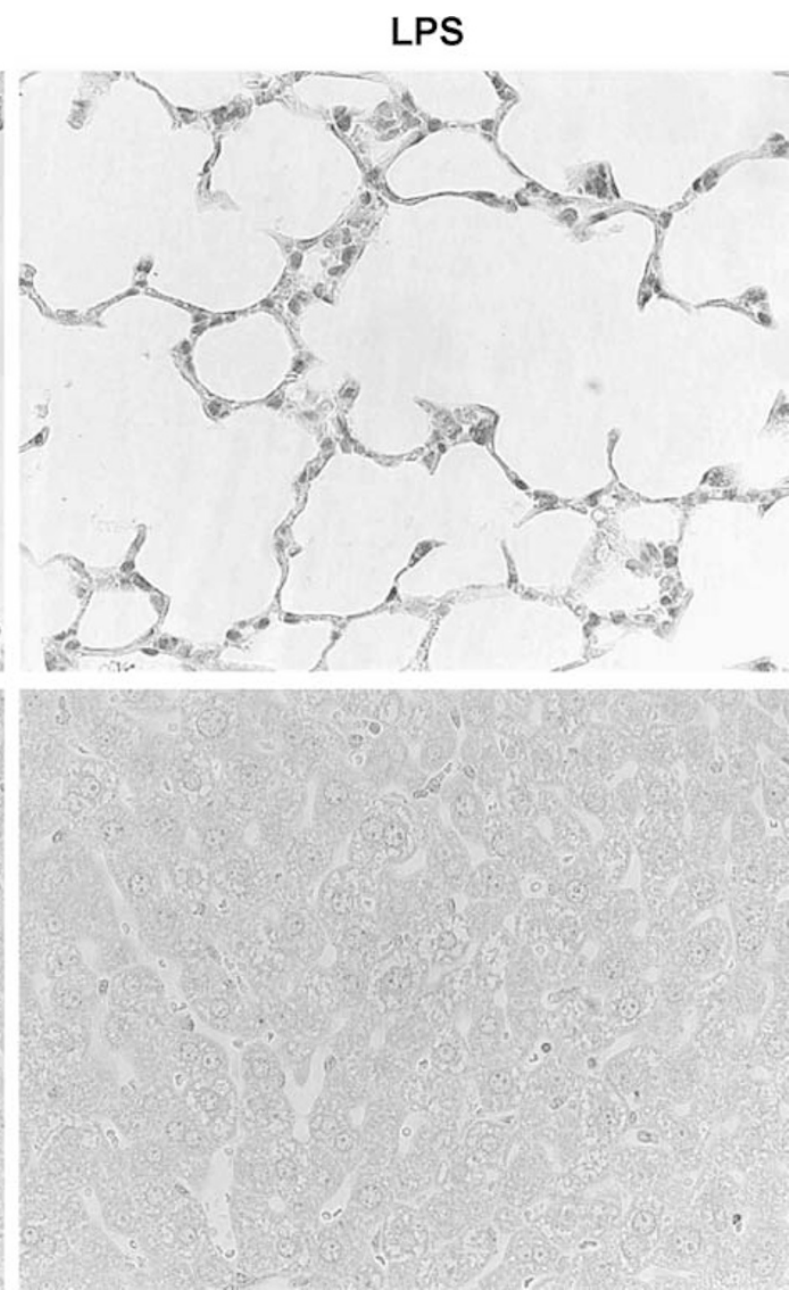

Figure 3 In situ nick-end labeling specific for fragmented DNA. BALB/c mice were primed i.v. with $\alpha$-GalCer ( $1 \mu \mathrm{g}$ ), and $12 \mathrm{~h}$ later, injected i.v. with LPS (5 $\mu \mathrm{g})$. The lungs and livers were removed $8 \mathrm{~h}$ after LPS injection and stained by TUNEL $\times 400$.

Table 4 Effect of $\alpha$-GalCer on LPS-induced lethality in NKT-deficient BALB/c mice

\begin{tabular}{lcccc}
\hline Mouse & $\alpha$-GalCer $(\mu g)$ & Time $(h)^{\mathrm{a}}$ & LPS $(\mu g)$ & $\begin{array}{c}\text { Lethality } \\
\text { (dead/total) }\end{array}$ \\
\hline Wild (BALB/c) & 1 & 12 & 5 & $6 / 6$ \\
NKT deficient & 1 & 12 & 5 & $0 / 6$ \\
& & - & 1000 & $4 / 4$ \\
Wild (BALB/c) & 0 & - & 1000 & $4 / 4$ \\
NKT deficient & 0 & - & \\
\hline
\end{tabular}

${ }^{\mathrm{a}}$ Hours before LPS administration.

\section{High Level of Circulating IFN- $\gamma$ and TNF- $\alpha$ by the Administration of LPS into $\alpha$-GalCer-Sensitized Mice}

Effect of $\alpha$-GalCer sensitization on the levels of circulating IFN- $\gamma$ and TNF- $\alpha$ was examined (Figure 5). The levels of circulating IFN- $\gamma$ and TNF- $\alpha$ were compared by the administration of LPS into $\alpha$-GalCer-sensitized BALB/C mice or untreated mice. High level of circulating IFN- $\gamma$ was detected in mice sensitized with $\alpha$-GalCer before
LPS treatment, suggesting that $\alpha$-GalCer alone lead to a high output of circulating IFN- $\gamma$ (Figure 5, top). On the other hand, the injection of LPS alone induced no significant amount of IFN- $\gamma$. LPS did not affect the level of circulating IFN- $\gamma$, which was induced by $\alpha$-GalCer, and the same high level of circulating IFN- $\gamma$ continued up to $24 \mathrm{~h}$ (data not shown). In addition, $\alpha$-GalCer did not lead to IFN- $\gamma$ production in Va14-positive NKT-deficient mice (data not shown). As shown in Figure 5 (bottom), TNF- $\alpha$ was not detected in $\alpha$-GalCer-primed mice before LPS treatment and $\alpha$-GalCer alone did not cause TNF- $\alpha$ production. LPS markedly augmented TNF- $\alpha$ production in $\alpha$-GalCer-pretreated mice $1 \mathrm{~h}$ after the injection and the level of TNF- $\alpha$ rapidly decreased within $3 \mathrm{~h}$. On the other hand, LPS lead to an only small amount of TNF- $\alpha$ in unsensitized mice.

\section{Prevention of Lethal Shock with Anti-IFN- $\gamma$ Antibody and Anti-TNF- $\alpha$ Antibody}

It is known that $\alpha$-GalCer activates NKT cells and causes the release of INF- $\gamma \cdot{ }^{11,12}$ In order to clarify the 


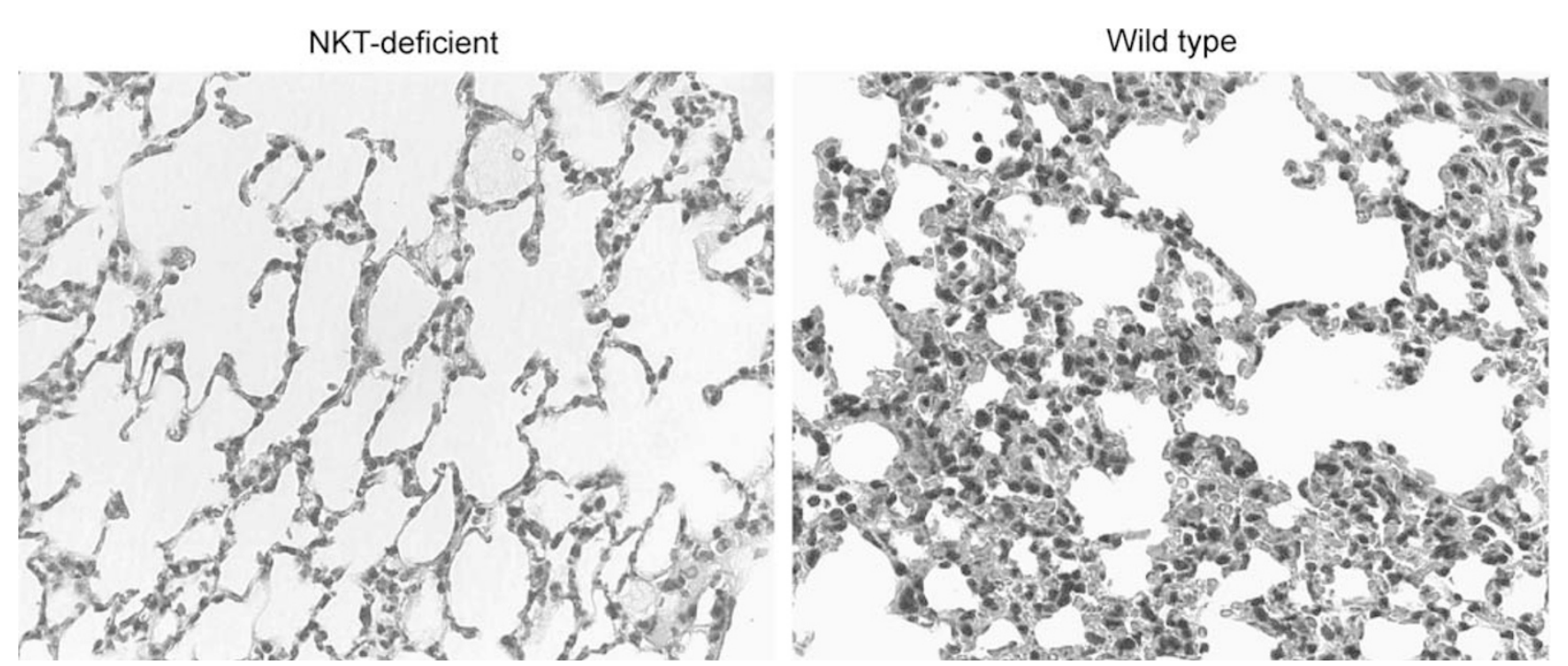

Figure 4 No development of the lethal shock in NKT-deficient mice. NKT-deficient and wild-type BALB/c mice were primed i.v. with $\alpha$-GalCer $(1 \mu \mathrm{g})$, and $12 \mathrm{~h}$ later, injected i.v. with LPS $(5 \mu \mathrm{g})$. The lungs were removed $8 \mathrm{~h}$ after LPS injection $\times 400$.
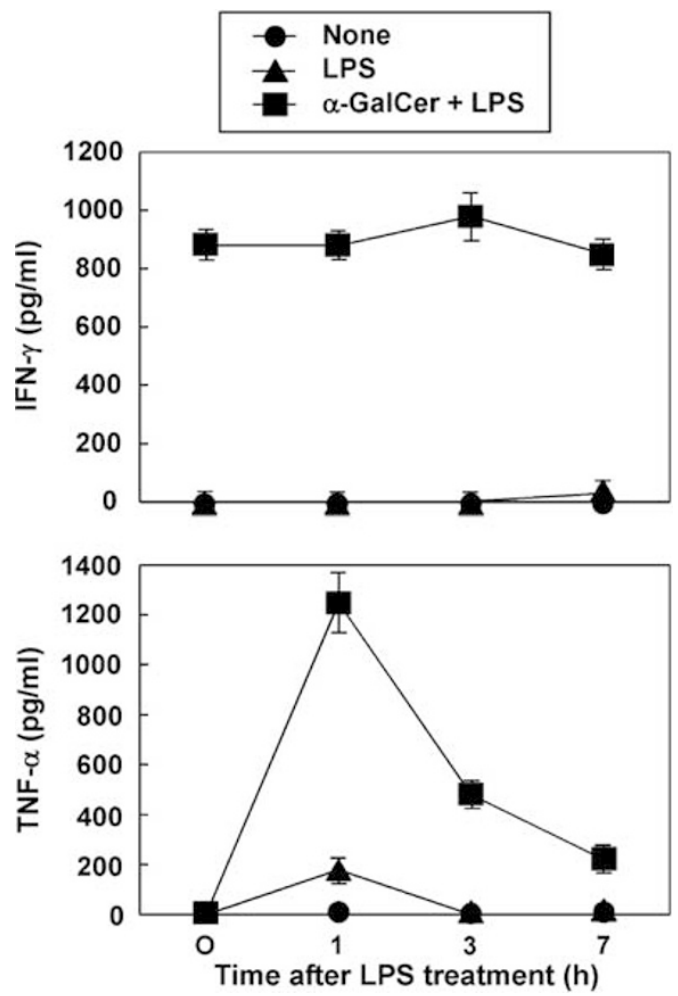

Figure 5 Circulating IFN- $\gamma$ and TNF- $\alpha$ by the administration of LPS into $\alpha$-GalCer-sensitized mice. The level of circulating IFN- $\gamma$ and TNF- $\alpha$ was determined before and after the administration of LPS into $\alpha$-GalCer-sensitized mice or untreated mice. Each value represents the mean \pm s.d. of triplicate samples.

involvement of IFN- $\gamma$ in the development of the lethal shock, the preventive effect of anti-IFN- $\gamma$ antibody or anti-TNF- $\alpha$ antibody on the lethal shock was examined (Table 5). Anti-IFN- $\gamma$ or TNF- $\alpha$ antibody was injected i.v. in $\alpha$-GalCer-sensitized BALB/c
Table 5 Prevention of LPS-mediated lethal shock by anti-IFN- $\gamma$ or TNF- $\alpha$ antibody in BALB/c mice

\begin{tabular}{lcccc}
\hline$\alpha$-GalCer $(\mu g)$ & \multicolumn{2}{c}{ Antibody ${ }^{\mathrm{a}}$ to } & LPS $(\mu \mathrm{g})$ & Lethality (dead/total) \\
\cline { 2 - 3 } & IFN- $\gamma$ & $T N F-\alpha$ & & \\
\hline 1 & + & - & 5 & $0 / 6$ \\
1 & - & + & 5 & $2 / 6$ \\
1 & - & - & 5 & $6 / 6$ \\
\hline
\end{tabular}

${ }^{\mathrm{a} A n t i-I F N}-\gamma$ antibody $(150 \mu \mathrm{g})$ and anti-TNF- $\alpha$ antibody $(50 \mu \mathrm{g})$ were injected i.v. $12 \mathrm{~h}$ before LPS injection.

mice, and $12 \mathrm{~h}$ later, the mice were challenged by LPS. The lethality was determined $24 \mathrm{~h}$ after LPS treatment. Anti-IFN- $\gamma$ antibody completely prevented $\alpha$-GalCer-sensitized mice from the development of LPS-mediated lethality, although all mice not receiving anti-IFN- $\gamma$ antibody were killed by LPS challenge. The development of pulmonary lesions was completely prevented by anti-IFN- $\gamma$ antibody. Anti-TNF- $\alpha$ antibody rescued four out of six mice from LPS-mediated lethal shock.

\section{No Induction of Systemic Lethal Shock in TNF- $\alpha$-Deficient Mice}

The inhibitory effect of anti-TNF- $\alpha$ antibody was partial (Table 5) and an excess of anti-TNF- $\alpha$ antibody did not appear to neutralize in vivo TNF$\alpha$ production completely, even though TNF- $\alpha$ is known as one of the main factor causing LPSmediated lethality. ${ }^{13,14}$ Therefore, the participation of TNF- $\alpha$ in the development of lethal shock was examined by using TNF- $\alpha$-deficient mice (Table 6). The administration of LPS killed $\alpha$-GalCer-sensitized wild-type B10.D2 mice, whereas it did not kill 
Table 6 Effect of $\alpha$-GalCer on LPS-induced lethality in TNF- $\alpha$-deficient B10.D2 mice

Mouse $\quad \alpha$-GalCer $(\mu g) \quad$ LPS $(\mu g) \quad$ Lethality (dead/total)

\begin{tabular}{llrl}
\hline B10.D2 wild & 1 & 5 & $6 / 6$ \\
TNF- $\alpha$ deficient & 1 & 5 & $0 / 6$ \\
TNF- $\alpha$ deficient & 1 & 20 & $0 / 6$
\end{tabular}

$\alpha$-GalCer-sensitized TNF- $\alpha$-deficient B10.D2 mice. Based on the finding that TNF- $\alpha$-deficient mice produced IFN- $\gamma$ normally in response to $\alpha$-GalCer (data not shown), the experimental result more clearly confirmed the involvement of TNF- $\alpha$ than that with anti-TNF- $\alpha$ antibody.

\section{Discussion}

In the present study, we demonstrate that the sensitization of mice with $\alpha$-GalCer causes lethal shock in response to LPS. The lethal shock is characterized by severe pulmonary failure with marked infiltration of inflammatory cells and massive cell death. Further, it was accompanied by mild hepatic injuries and systemic congestion. Therefore, it could be diagnosed as LPS-mediated systemic lethal shock. An animal model of severe sepsis should be characterized by these features: persistent hypermetabolism, low systemic vascular resistance, respiratory failure severe enough to require mechanical ventilation, late (nonpulmonary) organ system failure and death. ${ }^{1}$ In fact, all severely septic patients clinically manifest respiratory failure and ventilator dependence, and failure of organs other than the lungs typically occurs days to weeks after the onset of the septic process. ${ }^{1}$ Therefore, our model using $\alpha$-GalCer sensitization clearly presents respiratory failure and is consistent with clinical features of severely septic shock. Our model might be very useful for a laboratory model of severe sepsis and septic shock.

$\alpha$-GalCer is a glycolipid that has been identified as a ligand recognized by a special group of immune T cells, known as V $\alpha 14$ NKT cells. ${ }^{12,15-17} \alpha$-GalCer is a powerful activator of invariant V $\alpha 14$ NKT cells, causing them to produce immunoregulatory cytokines, especially IFN- $\gamma^{11,12}$ and interleukin-4..$^{18,19}$ Therefore, NKT cells are strongly suspected to be involved in the development of systemic lethal shock in the model using $\alpha$-GalCer. This hypothesis is also supported by the analysis with NKT-deficient mice. There is controversy on the requirement of NK cells and NKT cells for LPS-induced lethal shock. Heremans et $a l^{20}$ reported an essential role of IFN- $\gamma$ producing NK cells. Moreover, Emoto et al ${ }^{21}$ reported a critical role of NK cells, rather than V $\alpha 14$ NKT cells. On the other hand, Dieli et $a l^{22}$ reported a mandatory role of NKT cells by using NKT-deficient mice. The present study supports a critical role of
$\alpha$-GalCer-reactive V $\alpha 14$ NKT cells for LPS-mediated lethal shock. V $\alpha 14$ NKT cells are very possible to be involved in sepsis and septic shock in clinical setting.

The analysis using anti-IFN- $\gamma$ or TNF- $\alpha$ antibody and TNF- $\alpha$-deficient mice suggests a critical role of IFN- $\gamma$ and TNF- $\alpha$ in the development of LPSmediated lethal shock. The systemic lethal shock requires pretreatment with $\alpha$-GalCer, suggesting that IFN- $\gamma$ may play a pivotal role on preparation or sensitization for the lethal shock. On the other hand, TNF- $\alpha$ is suggested to be an execution factor for lethal shock. Probably, $\alpha$-GalCer activates V $\alpha 14$ NKT cells and leads to IFN- $\gamma$ production. Released IFN- $\gamma$ renders mice susceptible for the shock and also induces augmented production of TNF- $\alpha$. An excess of TNF- $\alpha$ damages various organs, especially lungs and finally cause multiple organ failure due to systemic lethal shock. This hypothetical idea is consistent with the pathogenesis of generalized Shwartzman reaction. The respective role of IFN- $\gamma$ and TNF- $\alpha$ in the development of generalized Shwartzman reaction has been reported by several groups. ${ }^{23-27}$ IFN- $\gamma$ renders the mice more sensitive to the reaction and plays a regulatory role. On the other hand, TNF- $\alpha$ functions as an execution factor and causes systemic lethal shock in mice. Our model corresponds to the pathophysiology of generalized Shwartzman reaction. Once again, IFN- $\gamma$ is most likely to be essential for sensitization and priming of the lethal shock.

Interestingly, our model features respiratory failure with severe pulmonary inflammation and is characterized by few hepatic lesions and endothelial injuries, compared to other lethal shock models with D-galactosamine, ${ }^{2} P$. parvum ${ }^{3}$ and BCG. ${ }^{4}$ As far as we know, this is the first report on systemic lethal shock characterized by respiratory failure. The severity of lesions does not necessarily correspond to the tissue distribution of NKT cells. It is still unknown how $\alpha$-GalCer-sensitized mice causes severe pulmonary lesions in response to LPS. Additionally, the lethal shock with $\alpha$-GalCer sensitization can be produced much more easily than other models for lethal shock.

The systemic lethal shock in the present study appears to be an endotoxic shock, since LPS is administered to $\alpha$-GalCer-sensitized mice. However, it appears that other microbial products, such as CpG DNA and peptideglycan, which are able to cause TNF- $\alpha$ production, can also trigger the lethal shock. Our model using $\alpha$-GalCer might be applied to systemic lethal shock with various microbial products.

\section{Acknowledgements}

This work was supported by in part by a Grant-inAid for Scientific Research from the Ministry of Education, Science, Sports and Culture of Japan. We 
are grateful to Dr T Nakayama and Dr M Taniguchi for providing V $\alpha 14$ NKT-deficient mice and Dr K Saito and Dr K Sekikawa for providing TNF- $\alpha$-deficient mice. We thank Kirin Brewery Company for providing synthetic $\alpha$-GalCer. We are also grateful to $\mathrm{K}$ Takahashi and A Morikawa for the excellent technical assistance.

\section{References}

1 Fink MP, Heard SO. Laboratory models of sepsis and septic shock. J Surg Res 1990;49:186-196.

2 Galanos C, Freudenberg MA, Reutter W. Galactosamineinduced sensitization to the lethal effects of endotoxin. Proc Natl Acad Sci USA 1979;76:5939-5943.

3 Ferluga J, Allison AC. Role of mononuclear infiltrating cells in pathogenesis of hepatitis. Lancet 1978;2:610-611.

4 Suter E. Hyperreactivity to endotoxin in mice infected with BCG. Studies on the role of concomitant infection. J Immunol 1962;89:377-381.

5 Cornelie S, Wiel E, Lund N, et al. Cytosine-phosphateguanine $(\mathrm{CpG})$ motifs are sensitizing agents for lipopolysaccharide in toxic shock model. Intens Care Med 2002;28:1340-1347.

6 Thomas L, Good RA. Studies on the generalized Shwartzman reaction: I. General observations concerning the phenomenon. J Exp Med 1952;96:605-624.

7 Ito H, Koide N, Morikawa A, et al. Augmentation of lipopolysaccharide-induced nitric oxide production by alpha-galactosylceramide in mouse peritoneal cells. J Endotoxin Res 2005;11:213-219.

8 Cui J, Shin T, Kawano T, et al. Requirement for Valpha14 NKT cells in IL-12-mediated rejection of tumors. Science 1997;278:1623-1626.

9 Gavrieli Y, Sherman Y, Ben-Sasson SA. Identification of programmed cell death in situ via specific labeling of nuclear DNA fragmentation. J Cell Biol 1992;119: 493-501.

10 Zhang XM, Morikawa A, Takahashi K, et al. Localization of apoptosis (programmed cell death) in mice by administration of lipopolysaccharide. Microbiol Immunol 1994;38:669-671.

11 Carnaud C, Lee D, Donnars O, et al. Cross-talk between cells of the innate immune system: NKT cells rapidly activate NK cells. J Immunol 1999;163:4647-4650.

12 Kitamura H, Iwakabe K, Yahata T, et al. The natural killer T (NKT) cell ligand alpha-galactosylceramide demonstrates its immunopotentiating effect by inducing interleukin (IL)-12 production by dendritic cells and IL-12 receptor expression on NKT cells. J Exp Med 1999;189:1121-1128.

13 Lehmann V, Freudenberg MA, Galanos C. Lethal toxicity of lipopolysaccharide and tumor necrosis factor in normal and D-galactosamine-treated mice. J Exp Med 1987;165:657-663.
14 Beutler B, Mahoney J, Trang NL, et al. Purification of cachectin, a lipoprotein lipase-suppressing hormone secreted by endotoxin-induced RAW 264.7 cells. J Exp Med 1985;161:984-995.

15 Kawano T, Cui J, Koezuka Y, et al. Natural killer-like nonspecific tumor cell lysis mediated by specific ligand-activated Valpha14 NKT cells. Proc Natl Acad Sci USA 1998;95:5690-5693.

16 Nieda M, Nicol A, Koezuka Y, et al. Activation of human Valpha24NKT cells by alpha-glycosylceramide in a CD1d-restricted and Valpha24TCR-mediated manner. Hum Immunol 1999;60:10-19.

17 Hayakawa Y, Godfrey DI, Smyth MJ. Alpha-galactosylceramide: potential immunomodulatory activity and future application. Curr Med Chem 2004;11: 241-252.

18 Tomura M, Yu WG, Ahn HJ, et al. A novel function of Valpha14+CD4+NKT cells: stimulation of IL-12 production by antigen-presenting cells in the innate immune system. J Immunol 1999;163:93-101.

19 Burdin N, Brossay L, Kronenberg M. Immunization with alpha-galactosylceramide polarizes CD1-reactive NK T cells towards Th2 cytokine synthesis. Eur J Immunol 1999;29:2014-2025.

20 Heremans H, Dillen C, Damme JV, et al. Essential role for natural killer cells in the lethal lipopolysaccharideinduced Shwartzman-like reaction in mice. Eur J Immunol 1994;24:1155-1160.

21 Emoto M, Miyamoto M, Yoshizawa I, et al. Critical role of NK cells rather than V alpha 14(+) NKT cells in lipopolysaccharide-induced lethal shock in mice. J Immunol 2002;169:1426-1432.

22 Dieli F, Sireci G, Russo D, et al. Resistance of natural killer T cell-deficient mice to systemic Shwartzman reaction. J Exp Med 2000;192:1645-1652.

23 Heremans H, Damme JV, Dillen C, et al. Interferon gamma, a mediator of lethal lipopolysaccharideinduced Shwartzman-like shock reactions in mice. J Exp Med 1990;171:1853-1869.

24 Koide N, Abe K, Narita K, et al. Apoptotic cell death of vascular endothelial cells and renal tubular cells in the generalized Shwartzman reaction. FEMS Immunol Med Microbiol 1996;16:205-211.

25 Koide N, Abe K, Narita K, et al. Expression of intercellular adhesion molecule-1 (ICAM-1) on vascular endothelial cells and renal tubular cells in the generalized Shwartzman reaction as an experimental disseminated intravascular coagulation model. FEMS Immunol Med Microbiol 1997;18:67-74.

26 Billiau A, Heremans H, Vandekerckhove F, et al. Antiinterferon-gamma antibody protects mice against the generalized Shwartzman reaction. Eur J Immunol 1987;17:1851-1854.

27 Doherty GM, Lange JR, Langstein HN, et al. Evidence for IFN-gamma as a mediator of the lethality of endotoxin and tumor necrosis factor-alpha. J Immunol 1992;149:1666-1670. 